\title{
Governing Systems: Modernity and the Making of Public Health in England, 1830-1910
}

Review Number: 2166

Publish date: Thursday, 7 September, 2017

Author: Tom Crook

ISBN: 9780520290341

Date of Publication: 2016

Price: $£ 27.95$

Pages: 408pp.

Publisher: University of California Press

Publisher url: http://www.ucpress.edu/book.php?isbn=9780520290358

Place of Publication: Oakland, CA

Reviewer: Christopher Hamlin

Tom Crook has written a big book - big in scope, range, and thought. It is both an overview of the institutionalization of public health in England and an interpretation of that event as paradigmatic of the systems and practices of pervasive governance that constitute modernity. Governing Systems is a double entendre - not only do public health-related systems do the work of governing, they themselves may require governing - though it is not clear they get it.

Crook's period - the sanitary inquires of the 1830s to the consolidation that would finally bring a Ministry of Health in 1919 - has been seen as a golden age. The sanitation-centered approach, later supplemented with modest surveillance, was significantly successful, contributing to a mortality decline that was more rapid than in the differently-focused approaches of other European nations. But public health had more than merely sectoral importance. It became a moral foundation, in England and beyond. The English infrastructure-based model of the intimate relation of cleanliness to civilization spread across the empire and would become in the post-colonial world a key metric of 'development'. That 'development' in turn strikes at the heart of what historians have often seen as most important and most commendable about the public health movement - that it was public. It showed governments behaving well, overcoming expense and opposition to provide citizens with necessaries of life, particularly water and sanitation. Representing the union of rights and rationality, it still resonates strongly in progressive politics - for even when the market is the instrument for service delivery, it is the state that is responsible. Hence Crook's topic, the institutionalization of public health, was not only historically pivotal in a so-called Victorian revolution in government, it was part of a much grander transformation, even, in the views of some, an apotheosis in which the state comes finally to its ideal form as guarantor of human well-being.

As it has been over a generation since a work of this scope has appeared (and closer to two since Victorian state-building was a popular topic among historians), it is worth exploring that telos. In those earlier days, the history of public health existed at the intersection of social and political history. The grand story that Crook, following Dorothy Porter, calls 'heroic' (pp. 5-6) was founded in the moralizing social histories of industrialisation and urbanization of the Hammonds and Karl Polanyi. It flourished in the two post-war (and post NHS) decades: it then seemed possible to see the period in terms of a single trajectory of achievement 
based in growing awareness, sensitivity, and rationality, through a process retrospectively understood as analytical Benthamism infused with a tincture of humanitarianism.

So what happened? In a nutshell, Michel Foucault and Roy Porter came on the scene, the former reversing the polarity of the Benthamite state (from 'heroic' to 'antiheroic') and the latter shifting historians' attention from earnest Victorians to relaxed, witty, elegant, Georgians. Suddenly the state seemed overwhelming as well as overweening, even hostile - in confining the insane, bullying sex workers, demanding vaccination, and intimidating the poor (not to mention conquering the world). The curious link between public health and the new poor law suddenly came into focus: constructs of the same governmental unit, both pursued the mission of disciplining persons into compliant productivity. There remained modest interest in local public health achievement, sometimes reflecting a view that the local, not the grandstanding state, was where the action was - for it should be kept in mind that the rise to prominence of Foucault and Porter coincided with that of Thatcherism. And many, smitten with the utopian bliss of a rational and humane 'public sphere,' downplayed government, local as well as national, altogether.

The persons (along with their professions and practices) who interest Crook fit into none of these stories. They are the minions who actually did the work of public health, whether haunting the back corridors of Whitehall or sallying forth from the back rooms of the new town halls. Crook rightly recognizes the absence of a critical core for studying the practices of governance.(1) At the national (and colonial) scale, we have 'variation upon variation' in various sector- or place-specific case studies (p. 7). And the study of localities seems to defy comprehensiveness: on so important a matter as water supply, the words, 'parish-pump', already shout irrelevance.

To better characterize Crook's approach it may help to untangle three distinct meanings of 'public health' that confuse the historiography. One, concerned with actual conditions, is demographic, epidemiological, and material. A second refers to a moral imperative for maintaining or improving population health that governments may or may not recognize. The third is institutional and administrative - it mediates between imperatives and conditions. Often seen as merely executory and derivative, it was under-explored in earlier work - as if an act of parliament was a problem solved. But the welter of obscure professions, masters of physical, informational, and judicatory technologies, and of administrative systems are Crook's core: they represent a pervasive power that bypasses or transcends ministries and legislatures. Whatever their ostensible politics, these systems had lives of their own, manifesting not 'government' but 'governance'.

Though I would wish for greater attention to the intersection of these systems with the other 'public healths' - material conditions and legislative achievement - Crook's focus seems wholly justified: given its immense importance in modern life, it is surprising how uniformly historians have avoided poking at that great sleeping hulk, the Victorian-Edwardian administrative state. But how to probe it? Crook focuses on several discrete areas: vital statistics (particular raw mortality data), inspection (chiefly by local sanitary inspectors, who initially bear the wonderful title, 'inspectors of nuisances'), wastes disposal (as an indicator of the importance of technical practices), epidemiological policing, and personal cleanliness, chiefly as involving water- and soap-use.

But narration and explanation in these areas is harder than it may seem, especially if one does not invoke the other two 'public healths'. Crook pretty consistently does not, and for some good reasons. As he makes clear most sharply in an early chapter, the 'material conditions' summoned at the time and since to justify action (senses one and two), were the creations of the third: there can be no vital statistics without vital statists - it is they who collect and order this information to point the finger at irresponsible authority or declare 'intolerable' filth (p. 105). Recognition of the enormous dominion of these forms of governance involves also understanding their substantial independence from the 'tired and overburdened paradigm of the state'. For, evidently, states are what states do. As Crook puts it 'this is what governing is - designing, operating, critiquing systems' (p. 290).

Seeking to make the suggestion less radical, he observes that there have always been practices, more or less 
systemic. Over the course of the century, however, practices in particular areas become increasingly more 'methodical, orderly, and efficient, which is to say, systematic' (pp. 290, also 26). As they affected ever larger numbers ever more deeply, growing in 'logistical complexity' while retaining 'reforming ambition', they begat the mass society known as 'modernity' (p. 14).

Notwithstanding occasional hints of reification, Crook's system of systems is in general modest and empirical. That by the end of the century a panoply of public health-related routines had become the stuff of ordinary English life seems undeniable. So too, it seems clear that some spirit of coordination and rationalization operated within and among them. That governance occurred as physical, procedural, and conceptual structures. Yet Crook cautions us: systematization neither produced perfection nor reflected a public health telos: there was no 'reform that was not mangled in practice and subject to partial and variable realization', he observes (p. 288). Indeed occasionally he apologizes for the continuing chaotic character of these 'systems'.

Yet modesty brings its own problems. As Crook admits, 'the term system js a slippery one' (p. 290). Indeed In the absence of a political architectonic or of the relentless force of circumstance (senses one and two of 'public health'), it is often unclear what is at the heart of these systems and what should guide narration and explanation. Recognizing 'systems' rather than, say, parliamentary mandates allows 'a more diffuse understanding of power and agency' (p. 10), he points out, yet at some level of diffuseness, agency evaporates. On the other hand, it can be difficult to distinguish a system from a narrative of a system for both are impositions of order (p. 20).

Crook does see a beginning, however, an initial utopianism connected to if not identical with the 'sanitary idea' taking shape in the 1830s. It was then that 'a series of modern dynamics concerning different levers, agents, and temporalities of governance began to combine, thereby structuring how England's public health system was conceived and practiced, reformed and frustrated' (p. 288). But this was no simple matter of the 'technocratic radicalism' associated with Edwin Chadwick. Crook identifies multiple ideologies, whose partial antitheses did not ultimately block a synthesis of some sort. Along with the Benthamite emphasis on the carefully designed 'invisible hands' of water and sewerage was a quite separate call for a medical dictatorship. Here Henry Wyldbore Rumsey was the most significant figure. On the other extreme, the iconoclast antiquarian Joshua Toulmin Smith emphasized radical democracy. Health and cleanliness would continue to be, as they had always been, achievements of free citizens perpetuating Saxon democratic tradition through common law. Finally, left to coordinate all this was Whig reformism. It was more a matter of role than substance, for it was the burden of aristocrats to pursue the common good by cautiously extending tradition on the basis, as needed, of targeted inquiry and expert analysis.

If systematization had a beginning did it have a center? Other than Whitehall? While Crook does not address the question directly, he does find several key centers of system-making. Among the most important were the new professional associations (e.g. the Association for Sanitary Inspectors) or transdisciplinary sectoral organizations (e.g. the Sanitary Institute of Great Britain). Trade journals were important too, particularly The Sanitary Record, vastly underutilized by historians. In terms of integration, the exemplar was the National Association for the Promotion of Social Science (NAPSS), one of several institutions modeled on the British Association for the Advancement of Science. As Lawrence Goldman has demonstrated, NAPSS allowed remarkably widely-ranging discussions of sometimes radical reform suggestions to occur in an extraparliamentary setting.(2) Crook opens his book with one of the best known of these, the maverick physiologist and temperance reformer Benjamin Ward Richardson's 1876 presidential address, in which he described Hygeia, a sanitarian utopia.

Does it all work? Partly. Within a finite book, Crook cannot get into the breadth and the depth that a compelling case would require. There is tension between the book's two main missions - to survey and account for changes in institutions and cultures of health, and to defend claims of systematicity and modernity. I shall comment on both. 
First, though Crook's book is by no means short, it is worth keeping in mind that the more narrowly focused works of the 'heroic' public health historians were often substantially longer. Anthony Wohl's 1983 Endangered Lives, still the most comprehensive survey of conditions and responses, was 440+ pages; the biography-based approaches of Samuel Finer and R. A. Lewis (on Chadwick), and Royston Lambert (on John Simon) took 400-600+ pages.(3) These authors wrote too at a time of greater interest in detailed political history and of greater sensitivity to the birth struggles of the welfare state. Crook does not have that luxury. His choice of topics is certainly defensible. As I have suggested, each chapter surveys not only its subject but the kinds of problem that subject exemplifies. The vital statistics chapter is not only about the use of mortality data, but about information collection and digestion. That on inspection is not just about inspectors of nuisances (Crook and I being as far as I know the only humans who find this topic riveting), but about the delicate, pervasive, and strangely intimate relations between state and citizen. The chapter on wastes disposal represents technological systems in general, that on coordinated epidemiological intelligence on the far-reaching (even international) command of bodies, while the last, on personal hygiene, reminds us that the systems existed in private or semi-private settings too.

One important topic is missing. To understand how practices of governance took on lives of their own, we have to look more closely their ties to the official state too: we cannot escape close examination of the workings of the Local Government Board and its predecessor and companion entities. For, however inadequate, there were centers. Though assignment to the LGB was often a despised appointment for an ambitious MP (not only was it a post of routine administration but of trivial matters), law-making (and the law) did affect practices. Any reader who pages through the huge volumes of correspondence between a local authority and the central state housed in the National Archives (under a Ministry of Health heading even though they deal with matters far beyond health) will see the growing systematicity Crook describes a transition from ad hoc governing, as officials confront problems that seem unique, to a recognition, first ethical and later sometimes cynical, that equitable (and efficient) administration means applying rules. If there is a dynamic here, it is that of casuistry: every problem has its proper taxon, even if sometimes a Solomonic senior official must be summoned to detect its essence. Through Roy MacLeod made an excellent start on the problem, I know of no close study of how this great bureaucracy actually worked. Crook continues to rely on the excellent 1988 study by the political scientist Christine Bellamy, though her issues were not his.(4) At the local level too there was a center of systematizing - the clerk of the local authority, effectively its CEO, CFO, ethicist, and ambassador, and certainly the impresario of most local public health systems.

These are domains too in which systematicity will be challenged by various forms of negotiation. One feature of Crook's treatment is the relative absence of conflict. Conflict loomed large in the older history in both the 'heroic' and 'antiheroic' modes. The history of public health was, as I have suggested, a battle ground for 'social justice'.(5) Often the documentary sources on which such judgments were made were themselves instruments of that partisanship.

'Systems' suggests innocuous rationalization rather than conflict ('practices,' is even more de-natured). If, sometimes, the systems Crook describes resolved conflicts, to appreciate them fully requires acknowledging that conflict: if it was sometimes subtle in other public health practices, conflict was graphic in capitalintensive sanitary infrastructure. Earlier writers noted a struggle between 'reformers' and a 'dirty party' of economizers, but even if we abandon such partisan representation, conflict was pervasive simply because choice was involved: the necessary works had to be in one place rather than another, of one design rather than another. There were geographic common problems. Water supply, for example, was almost always a matter of adjudicating costs and benefits - thus the Thames Conservancy was empowered to harass upstream Thames towns to impede natural flow of their sullied tributaries into London's water supply (6), while, as Harriet Ritvo has elegantly shown, Manchester was allowed to steal the waters of the northwestern lakes.(7) Something similar might be said regarding smoke. Often geography was proxy for class. (8) Among the most important duties of central bureaucrats was setting of boundaries of local authority (and rating) districts. Determining what the 'public' was often involved petitions alleging that 'we' and 'they' were not part of the 
same public.(9) Thus the allure of technocracy - a pretense that conflict can be denied.

All these are questions of dynamics. Exploring a welter of varied systems, Crook can say relatively little about the dynamics of each - whether class conflict or other forms of economic, technical, or even epidemiological rationalization (e.g. Chandler, Hughes, Luckin), including path dependence (e.g. Melosi). (10) His overlooking of such issues reflects his greater fascination with modernity itself - the form of governance that had arrived by the early 20th century - than with the process of getting there. That foreshortening under-represents not only contingency but complexity (and difficulty). Thus he notes early on that the diseases of concern in public health were 'bacterial and viral' (p. 2). Yet even if we substitute 'infectious diseases' for microbial agents, that wasn't unambiguously true in 1830 or even in 1870 . By no means do I want to suggest that changes in medical science drove changes in governance, but only that the rush to modernity obscures another important dynamic - the slow growth of expertise that can only be seen by closely following technical change over time.

Expertise in turn requires experts - including the sorts of persons Hughes would identify as 'systembuilders'.(11) Here too I find Crook's interest in the phenomenal aspects of governance - the systems as citizens confront them -- to come at the cost of a closer exploration of an expert-centric or problem centricstandpoint.(12) With regard to vital statistics, for example, it seems right to recognize that the technical tools of the quantitative social sciences were significantly different in 1910 from what they were in 1830 . Thus at the end of the period the first waves of the Pearsonian revolution were impacting governance: one could test the relative power of variables and use probable error to see if apparent relationships fell within the realm of random distribution.(13) Often, when one studies public health governance in a particular local authority over decades, one sees waves of novelty coming with personnel changes. The arrival of a newly trained engineer, inspector, or medical officer brings strikingly new methods. Hence we could certainly tell this story through expert biographies.

Though I find the gestures toward 'systems' and 'modernity' underdeveloped and the terms themselves probably unnecessary, the concerns above should register as complements not criticisms. It is rare to finish a reasonably lengthy book and wish it were longer. Crook has done much; there is need for much more. Crook's principal choice - to open our minds to the pervasiveness of public health governance that arose during the 19th century - is exactly right. He recognizes (pp. 9-11) that his approach does not replace those of heroic and antiheroic historians (I have tried to suggest some key intersections). But the most important contribution of this book will be (I hope) to stimulate research. There is so very much we do not know about very familiar elements of modernity. The potential source base is enormous. Crook relies mainly on underutilized printed sources of professional exchange, though he has sampled local archives too. But his book is not significantly based either on parliamentary papers - the great blue books with their mountains of tables and 10s of 1000s of technical questions and answers that were the staple of an earlier generation of historians of 19th-century government - or, as I have noted, on the tons of digested governance in the National Archives, not to mention in innumerable local archives. All these record key sites of professional practice. That much of this, along with the goldmine of local newspapers, is now digitized, makes such work possible, though daunting too - the sheer mass of materials may well deter students needing to produce a dissertation in finite time. Still, Crook's fine book gives me hope that historians will come back to (or, more properly, discover for the first time) a kind of research immensely important to the understanding of the present and the recent past, and long neglected.

\section{Notes}

1. Perhaps the best precursor of this approach is Herman Finer, English Local Government (London, 1933).Back to (1)

2. Lawrence Goldman, Science, Reform, and Politics in Victorian Britain the Social Science Association, 1857-1886 (Cambridge, UK, 2002).Back to (2)

3. Anthony S. Wohl, Endangered Lives: Public Health in Victorian Britain (Cambridge, MA, 1983); S. E. Finer, The Life and Times of Sir Edwin Chadwick (London, 1952); R. A. Lewis, Edwin Chadwick and the Public Health Movement, 1832-1854 
(London, 1952); Royston Lambert, Sir John Simon and English Social Administration (London, 1965). Back to (3)

4. Christine Bellamy, Administering Central-Local Relations, 1871-1919: The LGB in Its Fiscal and Cultural Context (Manchester, 1988); Roy M Macleod, Treasury Control and Social Administration: A Study of Establishment Growth at the Local Government Board, 1871-1905, Occasional Papers in Social Administration, 23 (London, 1968). Back to (4)

5. Christopher Hamlin, Public Health and Social Justice in the Age of Chadwick: Britain 1800-1854 (Cambridge, 1998).Back to (5)

6. Bill Luckin, Pollution and Control: A Social History of the Thames in the Nineteenth Century (Bristol, 1986). Back to (6)

7. Harriet Ritvo, The Dawn of Green Manchester, Thirlmere, and Modern Environmentalism (Chicago, IL, 2009). Back to (7)

8. To historians of a certain vintage, 'dialectic', will signal these issues, but Crook uses the term (p. 288) outside that context.Back to (8)

9. On the emergence of the 'public', see James G. Hanley, Healthy Boundaries: Property, Law, and Public Health in England and Wales, 1815-1872 (Rochester, NY, 2016). Seemingly simple, the creation of a uniform set of local authority districts applicable to most administrative needs was not significantly achieved until 1892, and has periodically been re-vamped ever since - for reasons of politics not governance (here again, my impression is of scholarly neglect - the best work remains $\mathrm{V}$. D. Lipman, Local Government Areas, 1834-1945 (Oxford, 1949).Back to (9)

10. Alfred D. Chandler, The Visible Hand the Managerial Revolution in American Business (Cambridge, MA, 1977); Thomas Parke Hughes, Networks of Power Electrification in Western Society, 1880-1930 (Baltimore, MD, 1983); Bill Luckin, Death and Survival in Urban Britain: Disease, Pollution and Environment, 1800-1950 (London, 2015); Martin V. Melosi, The Sanitary City: Urban Infrastructure in America from Colonial Times to the Present (Baltimore, MD, 2000). Back to (10)

11. Thomas Parke. Hughes, American Genesis: A Century of Invention and Technological Enthusiasm 1870-1970 (New York, NY, 1989).Back to (11)

12. Here Crook's separation of vital statistics (chapter three) from epidemiology (chapter eight), while understandable in terms of the kinds of policies he wants to emphasize, obscures the links between the two enterprises. Back to (12)

13. Alain Desrosières, The Politics of Large Numbers?: A History of Statistical Reasoning (Cambridge, MA, 1998). I am thinking here also of the sort of close attention the denominator problem that Eyler explores for William Farr. See John M. Eyler, Victorian Social Medicine: The Ideas and Methods of William Farr (Baltimore, MD, 1979). Back to (13)

Source URL:https://reviews.history.ac.uk/review/2166

\section{Links}

[1] https://reviews.history.ac.uk/item/161322 